\title{
The Impact of The Creativity Levels of The Students Who Study at The School of Physical Education and Sport on Therr Critical Thinking Dispositions
}

\author{
Osman Pepe ${ }^{1, *}$ \\ ${ }^{1}$ Erciyes University, Physical Education and Sport Department, Kayseri, Turkey \\ *Correspondence: Physical Education and Sport Department, Erciyes University, 38039, Kayseri, Turkey. Tel: \\ 90-507-235-7934. E-mail: opepe@erciyes.edu.tr
}

Received: June 21, 2018

Accepted: July 23, 2018 Online Published: October 25, 2018

doi:10.5430/wje.v8n5p185

URL: https://doi.org/10.5430/wje.v8n5p185

\begin{abstract}
The aim of this study is to examine the impact of the creativity levels of the students who study at the School of Physical Education and Sport on their critical thinking dispositions.

In accordance with this purpose, the sample is composed of 341 students randomly selected from the Erciyes University School of Physical Education and Sport. In the study, The California Critical Thinking Disposition Inventory which was adapted into Turkish by Kökdemir (2003), the creativity level scale adapted by Çoban (1999) and the "Personal Information Form" prepared by the researcher were used as data collection tools.

Statistical analyzes of the data obtained from the Personal Information Form were made with the SPSS 20.0 package program. Personal information about the candidates, total inventory scores and factor scores were given by determining their frequency (f) and percentage (\%) values. The Pearson Product-Moment Correlation analysis ( $\mathrm{r}$ ) was applied in order to reveal the relationship between the scores obtained from the scales and the multiple regression analysis $(\beta)$ was applied in order to determine whether the obtained scores were predictive of each other.

While a positively significant relationship was revealed between creativity and the critical thinking sub-dimensions curiousness, analyticalness, open-mindedness, truth-seeking, and self-confidence; a significant relationship could not be determined between creativity and the systematicity sub-dimension. Also, it has been determined that the critical thinking and creativity level scale scores were at medium level.

When the results obtained from our study are examined, it is seen that the level of creativity affected critical thinking methods as well as many other areas. For this reason, it is thought that it is important for the teacher training institutions to also include senior thinking skills in preparing their programs.
\end{abstract}

Keywords: critical thinking, creativity, physical education and sport

\section{Introduction}

It is necessary for humans by nature to be equipped with many skills in order to be able to sustain their life. One of these is creativity. The concept of creativity is often needed to solve problems that cannot be solved in family or business life, even though it is mostly associated with scientific discoveries or important works of art (Lau, 2011). Creativity is not just about creating a new product, it is about synthesizing all known information and then discovering different solutions or thinking about the functions of objects out of the ordinary (Karataş \& Özcan, 2010).

According to Dilek (2013) and Demirkale (2015), creativity is an entity that can be enhanced with education without specific limits. It can be said that creativity requires breaking out of the ordinary, being different, and being open-minded. It can be thought of as producing new routes instead of following a straight line. Creativity is a personal and social feature that has enabled mankind's progress throughout history (Leikin and Pitta-Pantazi, 2013).

According to MEB (2005), one of the other skills required besides creativity is critical thinking. Generally speaking, while creative thinking requires inquiry, examination, research and discovery, critical thinking requires departing 
from monotony, making profit and loss accounts and scrutinizing events. Both creativity and critical thinking are features that people who love examination, who are far from monotony, and who have strong cognitive activities can possess. When viewed from this aspect, it can be thought that both skills can be very close to each other in certain points and affect each other. It can be said at this point that people who have developed critical thinking and creativity skills can also reflect successful identity status features. Turan, Koç and Karaoğlu (2017) stated that individuals with successful identity status became stable after a period of high-quality research and examination but that this situation could also be related to education level, age, educational department and gender.

According to Ellis (2002), the critically thinking person makes claims based on solid evidence or logic by distinguishing between reality and thought, asking questions, making detailed observations, exposing assumptions and defining their circumstances. Critical thinking is the ability to distinguish between the accuracy and error ratings of interference, to recognize assumptions, to reason deductively, to predict and to evaluate claims (Chaill, M. \& Fonteyn, M. 2000). In addition, Kazu and Şentürk (2010) defined critical thinking as the reasonable and reliable way of thinking that brings the positive aspects of concepts into the forefront when making decisions about our lives. On the other hand, according to Nosich (2012), critical thinking is to try to understand the logic of concepts by questioning them and to draw conclusions from this logic. Both creativity and critical thinking tendencies are two of the most important personality traits that can influence and improve human life in various ways. When the body of literature is examined, it can be seen that personality traits affect many areas of our life, especially academic achievement (Koç, Turan and Karaoglu, 2017).

In the light of these explanations, the aim of this study is to examine the impact of the creativity levels of the students who study at The School of Physical Education and Sport on their levels of critical thinking and if there is any impact, to determine at what level. When the literature is examined, it is seen that the studies on the subject are very few especially in the field of physical education and sports. In this respect, it is thought that our study will contribute to the body of literature.

\section{Material Method}

\subsection{Study Group}

This research is in the relational screening model. This screening model can be defined as "...the research models aimed at determining the presence and/or level of covariance between two or more variables" (Karasar, 2007). The aim of this study is to examine the impact of the creativity levels of the students who study at The School of Physical Education and Sport on their critical thinking dispositions.

\subsection{Data Collection Tools}

During the application of the surveys to be done by the participants in the study, researchers tried to create a sufficient evaluation process for each of the participants by making the necessary explanations in a broad period of time without haste. In addition, suitable conditions were provided for the participants to fill out the forms in a comfortable setting. The data collection tools used in the study were arranged as follows; the Creativity Scale, the Critical Thinking Scale, and the Socio-Demographic Information Form.

\subsection{The Creation of the Volunteer Groups}

The research will be conducted through the study group. The study group consists of 1st, 2nd, 3rd and 4th grade candidates studying in the Physical Education and Sports Teaching, Coaching Education, Sport Management, and Recreation Education departments in the Erciyes University School of Physical Education and Sport.

A total of 341 students randomly selected from the 1470 students attending the School of Physical Education and Sport participated in the study. 
Table 1. The Socio-Demographic Features of the Participants

\begin{tabular}{cccc}
\hline & Variables & N & \% \\
\hline \multirow{2}{*}{ Gender } & Male & 189 & 55,4 \\
& Female & 152 & 44,6 \\
Age & $18-21$ & 116 & 34,0 \\
& $22-25$ & 182 & 53,4 \\
& $26-29$ & 43 & 12,6 \\
Department & Physical Education and Sports Teaching & 88 & 25,8 \\
& Coaching Education & 82 & 24,0 \\
& Sport Management & 89 & 26,1 \\
Grade & Recreation Education & 82 & 24,0 \\
& 2 & 122 & 35,8 \\
Cumulative & 3 & 124 & 36,4 \\
Grade Point & 4 & 95 & 27,9 \\
Average & $1.25-1.99$ & 36 & 10,6 \\
\hline
\end{tabular}

\subsection{Socio-Demographic Information Form}

While the socio-demographic information form of the study was being prepared, preparedness for self-regulated learning, critical thinking, and general self-efficacy in literature and the socio-demographic information forms were examined and a pool consisting of the features to be examined in the students was created. Afterwards, a socio-demographic information form was created with the help of statisticians. This socio-demographic information form is composed of 5 questions to obtain participants' age, gender, department, grade, and general academic grade average information.

\subsection{California Critical Thinking Disposition Inventory}

The "California Critical Thinking Disposition Inventory" is used to assess the critical thinking disposition of a person, or their level of critical thinking in a more comprehensive expression, not to measure a skill, unlike similar critical thinking scales (Kökdemir, 2003). This scale emerged as a result of the Delphi project organized by the American Philosophical Association in 1990 (Facione, Facione and Giancarlo, 1999). The adaptation work of the scale was carried out by Kökdemir (2003). For the findings on the reliability of the scale, the Cronbach alpha coefficients were calculated as .86 in the whole study, .82 in the curiousness sub-dimension, and the total item correlation coefficients were calculated as between .39 and .75 .

\subsection{The Creativity Level Scale}

The "How Creative Are You?" creativity scale, developed by Raudsepp (1977) and adapted into Turkish by Çoban (1999) was prepared by taking the individual's behavior, values, interests, motivations, personal features, and many other variables into consideration. There are 50 items on the scale. There are 23 positive and 27 negative items on the scale. The individuals whose scale points are between 100 and 80 are considered highly creative, while between 79 and 60 is considered above average, between 59 and 40 is considered intermediate, between 39 and -20 is considered below average, and between -19 and -100 is considered non-creative. The Cronbach alpha reliability coefficient of the scale adapted by Çoban (1999) was found to be .95 . In this study, the calculated Cronbach alpha value was found to be .86 , indicating that the scale could be used as a reliable measurement tool.

\subsection{The Analysis of the Data}

The data obtained from the Personal Information Form, the self-regulated learning preparedness scale, the critical thinking and general self-efficacy scale and the points obtained at the end of the study were coded and entered into the SPSS 2.0 package program and analyzes were made over this program. The personal information, the inventory total scores and the factor scores for the candidates were determined by determining the frequency (f) and percentage (\%) values. The Pearson Product-Moment Correlation analysis (r) was applied to reveal the relationship between the scores obtained from the scales and the Multiple Regression Analysis $(\beta)$ was applied to determine whether the obtained scores were predictive of each other. 


\section{Findings}

Table 2. The Descriptive Statistics of Students' Responses to the Questionnaire

\begin{tabular}{lcccc}
\hline & $\mathbf{N}$ & Minimum & Maximum & $\mathbf{X} \pm \mathbf{S D}$ \\
\hline Curiousness & 341 & 9.00 & 45.00 & $38.16 \pm 3.94$ \\
Analyticalness & 341 & 10.00 & 50.00 & $42.38 \pm 4.24$ \\
Systematicity & 341 & 6.00 & 30.00 & $25.39 \pm 2.86$ \\
Open-Mindedness & 341 & 12.00 & 60.00 & $50.55 \pm 5.15$ \\
Truth-Seeking & 341 & 7.00 & 35.00 & $29.61 \pm 3.22$ \\
Self-Confidence & 341 & 7.00 & 35.00 & $29.47 \pm 3.32$ \\
Creativity & 341 & 10.00 & 75.00 & $44.16 \pm 17.82$ \\
\hline
\end{tabular}

When Chart 2 was examined, from the critical thinking sub-dimensions, the average creativity dimension was calculated as 44.16 while the curiousness average was 38.16 , the analyticalness average was 42.38 , the systematicity average was 25.39, the open-mindedness average was 50.55, the truth-seeking average was 29.61, and the self-confidence was 29.47 .

Table 3. The Correlation Coefficients between students' Critical Thinking and Creativity Levels $(n=341)$

\begin{tabular}{|c|c|c|c|c|c|c|c|c|}
\hline & & 1 & 2 & 3 & 4 & 5 & 6 & 7 \\
\hline \multirow{4}{*}{ Curiousness $^{1}$} & $\mathrm{r}$ & 1 & & & & & & \\
\hline & $\mathrm{p}$ & & & & & & & \\
\hline & $\mathrm{n}$ & 341 & & & & & & \\
\hline & $\mathrm{r}$ & $.621^{* *}$ & 1 & & & & & \\
\hline \multirow{3}{*}{ Analyticalness $^{2}$} & $\mathrm{p}$ & .000 & & & & & & \\
\hline & $\mathrm{n}$ & 341 & 341 & & & & & \\
\hline & $\mathrm{r}$ & $.521^{* *}$ & $.607^{* *}$ & 1 & & & & \\
\hline \multirow[t]{3}{*}{ Systematicity $^{3}$} & $\mathrm{p}$ & .000 & .000 & & & & & \\
\hline & $\mathrm{n}$ & 341 & 341 & 341 & & & & \\
\hline & $\mathrm{r}$ & $.649^{* *}$ & $.593^{* *}$ & $.536^{* *}$ & 1 & & & \\
\hline \multirow[t]{3}{*}{ Open-Mindedness ${ }^{4}$} & $\mathrm{p}$ & .000 & .000 & .000 & & & & \\
\hline & $\mathrm{n}$ & 341 & 341 & 341 & 341 & & & \\
\hline & $\mathrm{r}$ & $.559^{* *}$ & $.637^{* *}$ & $.582^{* *}$ & $.592^{* *}$ & 1 & & \\
\hline \multirow[t]{3}{*}{ Truth-Seeking 5} & $\mathrm{p}$ & .000 & .000 & .000 & .000 & & & \\
\hline & $\mathrm{n}$ & 341 & 341 & 341 & 341 & 341 & & \\
\hline & $\mathrm{r}$ & $.570^{* *}$ & $.507^{* *}$ & $.382^{* *}$ & $.600^{* *}$ & $.545^{* *}$ & 1 & \\
\hline \multirow[t]{3}{*}{ Self-Confidence $^{6}$} & $\mathrm{p}$ & .000 & .000 & .000 & .000 & .000 & & \\
\hline & $\mathrm{n}$ & 341 & 341 & 341 & 341 & 341 & 341 & \\
\hline & $r$ & $.214^{*}$ & $.321 *$ & .156 & $.278^{*}$ & $.101 *$ & $.125^{*}$ & 1 \\
\hline \multirow[t]{2}{*}{ Creativity $^{7}$} & $\mathrm{p}$ & .034 & .010 & .054 & .018 & .026 & .038 & \\
\hline & $\mathrm{n}$ & 341 & 341 & 341 & 341 & 341 & 341 & 341 \\
\hline
\end{tabular}

When Chart 3 was examined, while a positively significant relationship was found between creativity and curiousness ( $\mathrm{r}=, 214$ $\mathrm{p}=, 034)$, a positively significant relationship was also found with the analyticalness $(\mathrm{r}=, 321 \mathrm{p}=, 010)$, open-mindedness $(\mathrm{r}=, 278$ $\mathrm{p}=, 018)$, truth-seeking $(\mathrm{r}=, 101 \mathrm{p}=, 026)$, and self-confidence $(\mathrm{r}=, 125 \mathrm{p}=, 038)$ sub-dimensions. A significant relationship could not be determined between creativity and the systematicity sub-dimension.

Table 4. The Regression Chart on the Students' Creativity Levels Predicting Their Critical Thinking Dispositions

\begin{tabular}{lcccccccc}
\hline & Critical Thinking & $\mathbf{B}$ & $\mathbf{T}$ & $\mathbf{P}$ & $\mathbf{R}$ & $\mathbf{R}^{\mathbf{2}}$ & $\mathbf{F}$ & $\mathbf{P}$ \\
\hline Creativity & & & & .064 & .027 & .398 & .000 \\
& Curiousness & .029 & .380 & .046 & & & & \\
Analyticalness & .009 & .107 & .015 & & & & \\
Systematicity & .079 & 1.057 & .060 & & & & \\
& Open-Mindedness & .037 & .448 & .033 & & & & \\
Truth-Seeking & .046 & .577 & .041 & & & & \\
& Self-Confidence & .058 & .786 & .045 & & & & \\
\hline
\end{tabular}

$\mathrm{F}(6,334)$ 
When Chart 4 was examined, it was seen that the model formed between creativity and critical thinking presented a significant relationship $(\mathrm{R}=, 064 \mathrm{R} 2=, 027 \mathrm{p}<.005)$. When the t-test results on the significance of the regression coefficient were examined, it was seen that the Curiousness $(\mathrm{t}=, 380 \mathrm{p}=.005)$, Analyticalness $(\mathrm{t}=, 107 \mathrm{p}=.015)$, Open-Mindedness $(\mathrm{t}=, 448 \mathrm{p}=.033)$, Truth-Seeking $(\mathrm{t}=, 577 \mathrm{p}=.041)$, Self-Confidence $(\mathrm{t}=, 786 \mathrm{p}=.045)$, and the Creativity features were predictive of the critical thinking disposition and that they explained $27 \%$ of the total variance $(\mathrm{F} 6,334=.398 \mathrm{p}<.005)$.

\section{Discussion and Conclusion}

The aim of this study was to examine the relationship between the creativity levels and the critical thinking dispositions of the students at the School of Physical Education and Sport. When the calculated results are examined; it is seen that there is a positively significant relationship between the creativity feature and the critical thinking sub-dimensions curiousness, analyticalness, open-mindedness, truth-seeking, and self-confidence. Creativity is only related at a low level to the systematicity sub-dimension.

Ak1llı (2012), in his study conducted on 256 students, found an positively significant relationship at an intermediate level between creativity levels and critical thinking skills. Bayrak (2014) came to the conclusion as a result of his study on the secondary school students at the middle socio-economic level that "the acquisition of critical thinking skills and dispositions and the development of the students' creativity should be among the goals of the modern education programs and thinking skills should be central in the learning process". Toyran (2015) found in a study on preschool teacher candidates that there was a positively significant relationship at a low level between critical thinking and creativity. As the creativity levels of the college-level people increase, they will be able to evaluate events from a broader perspective and look at them from different angles, thus becoming individuals who are remote from monotony, who are able to examine events thoroughly with the pluses and minuses, while being mindful of different aspects. It is therefore expected that the critical thinking skills of such individuals who produce new, genuine ideas can be high.

At the same time, analyticalness refers to the tendency to be cautious against potentially problematic situations and to use reasoning and objective evidence even in the face of difficult problems. The analytical person wants to know the reason and justification behind any proposed idea, is sensitive in the face of problematic cases, and wants to learn the results early. People with the curiousness sub-dimension are quite eager towards obtaining information, they learn about the explanations even if the application field of the information is not clear (Gülveren, 2007). Open-mindedness states the person's tolerance towards different approaches and their sensitivity towards their own mistakes. The basic logic in open-mindedness is that when an individual makes a decision, he is mindful not only of his/her own thoughts, but also of the opinions and thoughts of the person opposite. Truth-seeking measures the tendency to evaluate alternatives and different thoughts. Getting a high score from this subscale indicates that the person's possibility to seek the truth, ask questions, and act objectively even when data opposite to his own thoughts are in question is high. Self-confidence, as is evident from its name, reflects the person's confidence in his/her own reasoning process (Kökdemir, 2003). When the definitions of these sub-dimensions, which are the components of the critical thinking disposition, are examined, expressions such as reasoning, openness to new ideas, valuation of opinions, objective thinking, and reasoning process stand out. Similar expressions come to mind when it comes to creativity. Therefore, it is thought that people with a high level of creativity are able to view events from a critical standpoint.

On the other hand, the scale scores of both critical thinking and creativity features were found to be at an average level. When the sub-dimensions of critical thinking are considered, it is seen that the scores obtained from the scale are generally intermediate. In the study conducted by Beşoluk and Önder (2010) on 528 college students, it was found that the vast majority of the students had an intermediate level of critical thinking ability. Kartal (2012), found in his study on the science teacher candidates that the critical thinking level scores of the subjects were at an intermediate level. The found results show parallelism with the literature.

Consequently, it is seen in this study on teacher candidates that there is a significant relationship between critical thinking and creativity. In the days when the debates about the teacher training system in our country continue, the problems on how the educators should be educated and what qualities they should possess in this process still maintain their popularity (Turan, Erol and Karaoğlu, 2016). At this point, it is clearly known that both of these features are important in working life. It is therefore thought that it is extremely important for the institutions that educate teachers to improve the studies that develop these features and to take the necessary precautions. 


\section{Suggestions}

- The higher education programs that educate teachers need to be developed according to the modern world. Our curriculum is based on the constructivist educational approach, however, all education stakeholders insist on sustaining the traditional education system based on rote-learning in practice. Measures should be taken to avoid such negativities. The analysis-synthesis and evaluation skills should be central in the learning process, especially in the institutions that train teachers.

- Between the high-level thinking studies, for the development of skills such as critical thinking and creativity, emphasis should be placed on the activities that will encourage the individuals to read and that will steer them towards athletic, social, and artistic activities. At the same time, in these studies, schools should ensure the participation of educators and students in democratic areas where ideas can be comfortably expressed.

- When physical education and sports teachers start working, teachers should be supported on in-service training and panel and congress participation to improve their high-level thinking skills.

- The task of getting the students to adopt high-level skills such as critical and creative thinking should be undertaken by families as well as teachers. Necessary training should be given to the families to raise awareness.

\section{References}

Ak1ll, N. (2012). The Evaluation of the Critical Thinking Dispositions and Creativity Levels of Eighth Grade Primary School Students. (Unpublished Master's Thesis Kahramanmaraş: Sütçü İmam University Social Sciences Institute.

Bayrak Ç. (2014). The Impact of the Usage of the Cort 1 Thinking Program in the "Electricity in Our Life" Unit on the Academic Achievement, Scientific Creativity and Critical Thinking Dispositions of Students. (Unpublished Master's Thesis), Adnan Menderes University Institute of Science and Technology.

Beşoluk, Ş., \& Önder, İ. (2010). The Examination of Teacher Candidates' Learning Approaches, Learning Styles and Critical Thinking Dispositions. Elementary Education Online, 9(2), 679-693.

Chaill, M., \& Fonteyn, M. (2000). Using Mind Mapping to Improve Students' Metacognition., In J. Higgs \& M. Jones (Eds.), Clinical Reasoning in the Health Professions. Oxford, UK: Butterworth Heinemann, 214-221.

Çoban, S. (1999). The Relationship Between Managers' Levels of Creativity and Leadership Styles. Unpublished Master's Thesis, İstanbul: İstanbul University Institute of Social Sciences.

Demirkale, O. C. (2015). The Examination of the Contribution of the Visual Arts Subject to Creative Thinking Skills. Unpublished Master's Thesis, Karadeniz Technical University Institute of Education Sciences.

Dilek, A. N. (2013). The Effect of Socio-Cultural Features on Creative Thinking. Unpublished Master's Thesis, Osmangazi University Institute of Education Sciences.

Ellis N. C. (2002). Frequency effects in language processing: A review with implications for theories of implicit and explicit language acquisition. Studies in Second Language Acquisition, 24(2), 143-188. https://doi.org/10.1017/S0272263102002024

Gülveren, H. (2007). The Critical Thinking Skills of The Students at the Faculty of Education and the Critical Thinking Factors Affecting These Skills. Unpublished PhD Thesis, Dokuz Eylül University Institute of Education Sciences.

Karasar N. (2007). Scientific Research Methods (17th Ed.). Ankara, Nobel Publishing Distribution: 49-53.

Karataş, S., \& Özcan, S. (2010). The Effects of Creative Thinking Activities on Learners' Creative Thinking and Project Development Skills. Ahi Evran University Journal of Education Faculty, 11(1), 225-243.

Kazu, İ. Y., \& Şentürk, M. (2010). Teacher Opinions Concerning Development of Critical Thinking Skills by the Primary Curriculum. International Online Journal of Educational Sciences, 2(1), 244-266.

Koç. K, Turan. M.B., \& Karaoğlu, B. (2017). Investigation of the Relationship Between University Students' Personal Characteristics and Success Tendencies. The Turkish Online Journal of Educational Technology, Special Issue, 318-325.

Kökdemir, D. (2003). Decision Making and Problem Solving in Uncertainty Situations, Unpublished PhD Thesis, 
Ankara University, Institute of Social Sciences.

Lau, J. Y. (2011). An introduction to critical thinking and creativity: Think more, think better. John Wiley \& Sons, 23-26. https://doi.org/10.1002/9781118033449

Leikin, R., \& Pitta-Pantazi, D. (2013). Creativity and mathematics education: The state of the art. ZDM, 45(2), 159-166. https://doi.org/10.1007/s11858-012-0459-1

Nosich, G. M. (2012). Learning to Think Things Through: A Guide to Critical Thinking Across the Curriculum (Translator: Birsel Aybek), Ankara: Anı Publishing.

Raudsepp, E. (1977). How Creative Are You?. Personnel Journal, 1, 218-220.

Toyran G. (2015). The Examination of the Creative Thinking Levels and Critical Thinking Dispositions of Preschool Teacher Candidates In Terms of Certain Variables (Unpublished Master's Thesis), Dokuz Eylül University.

Turan, M.B., Erol, Z., \& Karaoğlu, B. (2016). The Analysis of Predictive Power on Teaching Profession's Features Of Attitude And Students' Levels Of Leadership In School Of Physical Education And Sports. Istanbul University Journal of Sport Science, 6(3), 1303-1414.

Turan, M.B., Koç. K., \& Karaoğlu. B. (2017). Analysis of Ego Identity Status of School of Physical Education and Sports. Universal Journal of Educational Research, 5(9), 1580-1588. https://doi.org/10.13189/ujer.2017.050915 